\title{
Gravity inferred subsurface structure of Gadwal schist belt, Andhra Pradesh
}

\author{
G RAMADASS, I B RAMAPRASADA RAO and N SRINIVASULU \\ Center of Exploration Geophysics, Department of Geophysics, Osmania University, Hyderabad 500 00\%, India
}

\begin{abstract}
Detailed gravity data collected across the Gadwal schist belt in the state of Andhra Pradesh show an 8.4 mgal residual gravity anomaly associated with meta-sediments/volcanics of the linear NNW-SSE trending schist belt that shows metamorphism from green schist to amphibolite facies. This schist belt is flanked on either side by the peninsular gneissic complex. The elevation and slab Bouguer corrected residual gravity profile data were interpreted using 2-D prism models. The results indicate a synformal structure having a width of $1.8 \mathrm{~km}$ at the surface, tapering at a depth of about $2.6 \mathrm{~km}$ with a positive density contrast of $0.15 \mathrm{gm} / \mathrm{cc}$ with respect to the surrounding peninsular gneissic complex.
\end{abstract}

\section{Introduction}

Detailed geophysical appraisal of the northern schist belts of the Dharwar craton, (i.e., the Gadwal, Hutti, Gurgunta Kustagi and Gadag green-stone belts) is not widely reported in literature. However, while Subramanyam $(1978,1982)$ and Appa Rao et al (1996) presented regional geophysical studies, aimed mainly at understanding the structure and evolution of the craton, Krishna Brahmam (1996) and Verma (1985) utilized gravity data to determine the thickness of the Dharwar schists. In continuation of such studies, in the present work the Gadwal schist belt has been studied in some detail.

Gadwal (latitude $16^{\circ} 14^{\prime} 55^{\prime \prime}$ and longitude $77^{\circ} 47^{\prime}$ $45^{\prime \prime}$ ) lies in the eastern Dharwar craton where theolitic and komaliitic meta-basalts and felsic volcanics formed $2700 \mathrm{Ma}$ (Balakrishna 1999 and Krogstad et al 1989) are the major rock types that constitute the gold mineralized belts. The Gadwal schist belt is a NNWSSE trending linear belt extending from Narayanpet in Mahboobnagar district, Andhra Pradesh in the north to Veldurthi in Kurnool district in the south (figure 1). The width of the belt varies between 1 and $10 \mathrm{~km}$ and it is flanked on either side by the peninsular gneissic complex. The lithology of this belt consists of basic, intermediate and acidic volcanics. Bands of iron formations, basic dykes, quartz veins and pegmatites have been reported (Anand Murty and Bhattacharjee 1997). Reddy (1992) reported gold mineralisation from bed rock pegmatites ( 0.035 to $0.25 \mathrm{ppm}$ ) and soil samples ( 0.035 to $4.25 \mathrm{ppm})$ in a shear zone marking the contact between massive meta-basalts and horneblende chlorite schist within the schist belt, following the general trend of the lithology.

In view of the relatively large modal density contrast reported between peninsular gneisses $(2.6-2.71 \mathrm{gm} / \mathrm{cc})$ and green-stone complexes (2.74-2.87 gm/cc), the major constituents of the study area, the gravity method was employed. Thus the present study, as discussed below, is aimed at understanding the gravity derived subsurface structure of the economically and scientifically important Gadwal schist belt.

\section{Gravity surveys}

Approximately 70 gravity observations were made using a station interval of $100 \mathrm{~m}$ along two nearly parallel profiles of $3.5 \mathrm{~km}$ length separated by $0.5 \mathrm{~km}$ (figure 1), extending well over the peninsular gneiss units on either side across the Gadwal schist belt. The gravity data was collected using a La Coste \& Romberg Model G gravimeter with practically negligible instrument drift with respect to time.

Keywords. Schist belt; subsurface structure; gravity-inferred basement 




Figure 1. Geological and geophysical layout map of the Gadwal schist belt area, Andhra Pradesh (after Ananda Murty and Bhattacharjee 1997). 


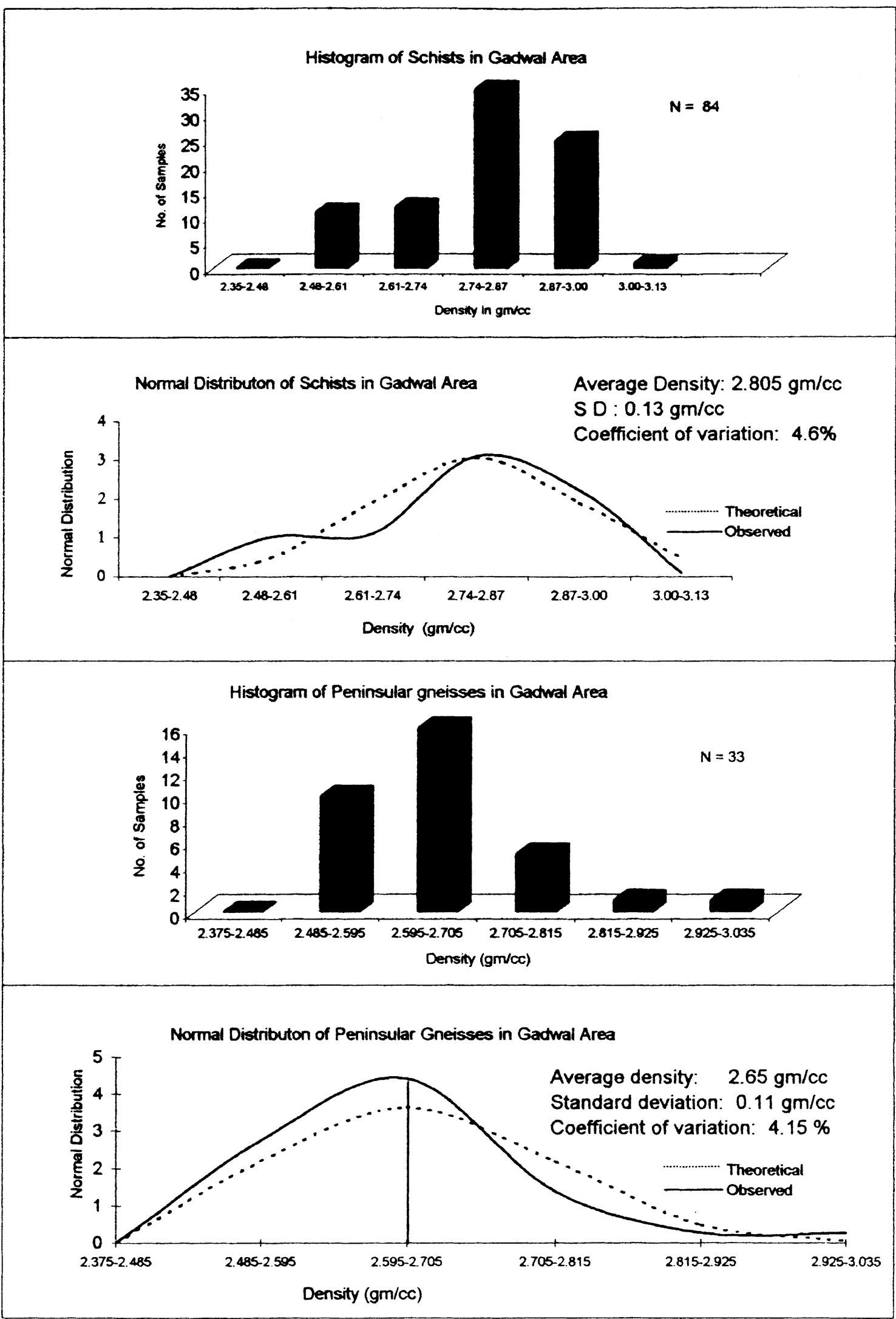

Figure 2. Histograms and distribution curves for densities of schists and peninsular gneissic complex in the Gadwal area - field distribution. 
Conventional surveying technique using the Sokia auto-level was utilized to obtain the relative elevations of the gravity stations. The elevations determined are accurate to $\pm 5 \mathrm{cms}$, which ensures associated combined free air and slab Bouguer error in the gravity anomaly of not more than $0.01 \mathrm{mgal}$.

\section{Data reduction and analysis}

\subsection{Density measurements}

Bulk densities of 84 samples of meta-sediments and 33 samples of peninsular gneiss from the study area were measured in the laboratory using a direct reading densitometer (Fedensky 1967) fabricated in the Department of Geophysics, Osmania University, Hyderabad, for proper analysis of the gravity data. An accuracy of $0.02 \mathrm{gm} / \mathrm{cc}$ is achievable with this system.

The density values for different geological formations in the area, mainly peninsular gneisses and schists vary over a wide range, from 2.38 to $3.04 \mathrm{gm} /$ cc for the former to $2.35 \mathrm{gm} / \mathrm{cc}$ to $3.13 \mathrm{gm} / \mathrm{cc}$ for the latter. Hence a statistical approach (Varaprasada Rao et al 1982) was adopted to study the variation phenomenon of these widely scattered belts.

The observed and theoretical values of densities for peninsular gneisses and schists have been presented as

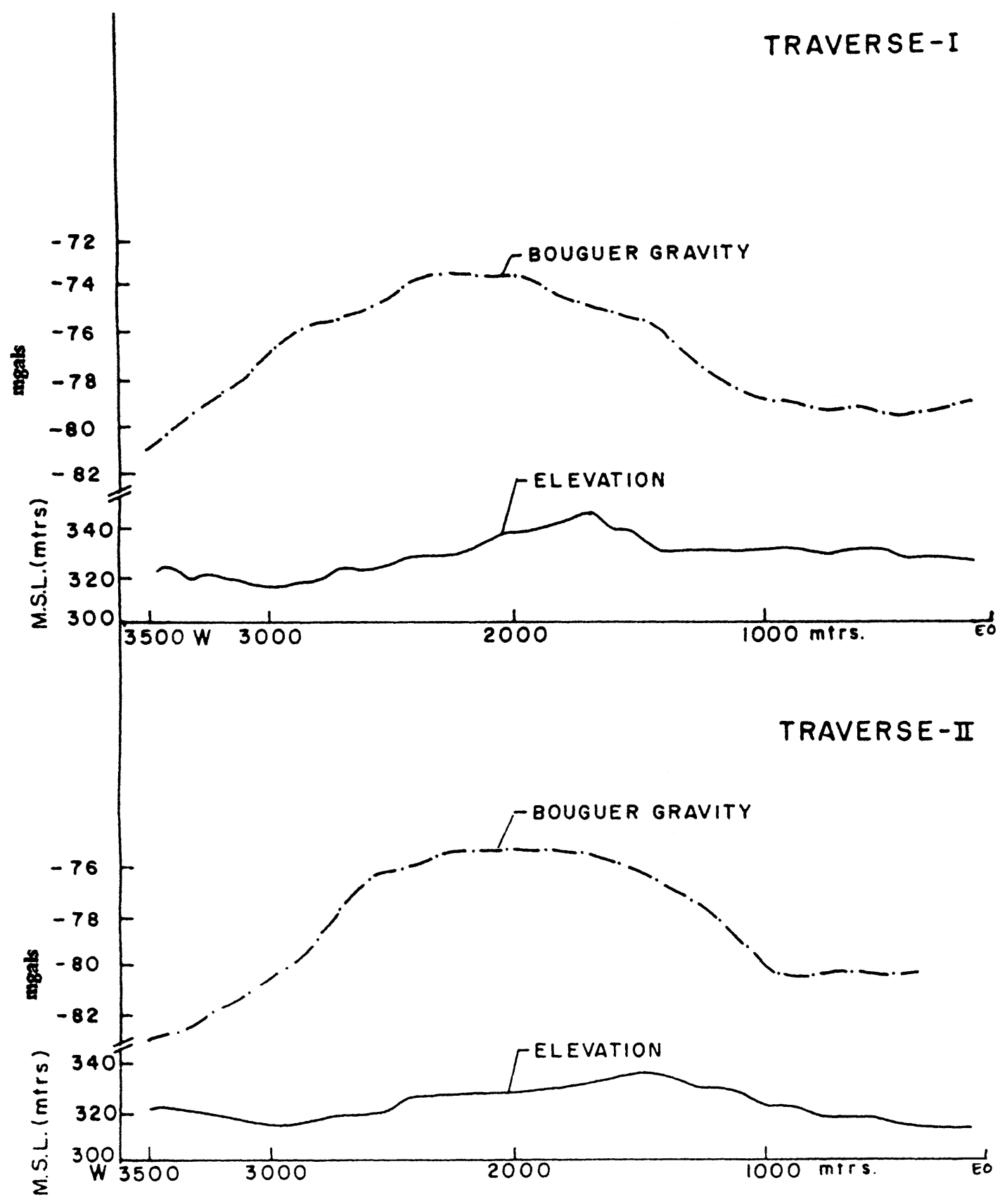

Figure 3. Observed gravity (Bouguer) and elevation values along traverses I and II of the Gadwal schist belt, Andhra Pradesh. 
distribution curves and bar diagrams (figure 2). The modal density of schist in the theoretical and field cases was found to be $2.81 \mathrm{gm} / \mathrm{cc}$.

On the other hand, the mean density of peninsular gneissic complex was found to be $2.65 \mathrm{gm} / \mathrm{cc}$. In this region this value can be taken to represent the background, or the crystalline basement density against which the gravity anomalies due to local geological variation can be interpreted. The standard deviation of $0.11 \mathrm{gm} / \mathrm{cc}$ of this observed density of $2.65 \mathrm{gm} / \mathrm{cc}$ with respect to the theoretical curve can be accounted for by the presence of samples affected by geological processes like weathering, silicification etc.

It can thus be concluded that a positive density contrast of $0.15 \mathrm{gm} / \mathrm{cc}$ exists between the schists and peninsular gneisses. As schists have higher densities and the peninsular gneisses lower densities, it is evident that schists are associated with gravity highs.

\subsection{Gravity measurements}

The gravity data obtained were reduced to the base station at Gadwal situated on the gneissic rocks at the beginning of profile I. The absolute gravity at this base is $978,309.9597 \mathrm{mgal}$, which was obtained by tying to the base at Raichur with absolute gravity of 978285.02 mgals (Manghnani and Wollard 1963).

For slab Bouguer correction, a constant mean density of $2.65 \mathrm{gm} / \mathrm{cc}$ was used Combined elevation and slab Bouguer corrected gravity anomaly profiles reduced to the chosen base are shown in figure 3 . The Bouguer gravity curve brought out the disposition of the schist belt by a distinct gravity high of the order of

TRAVERSE-I

(a)

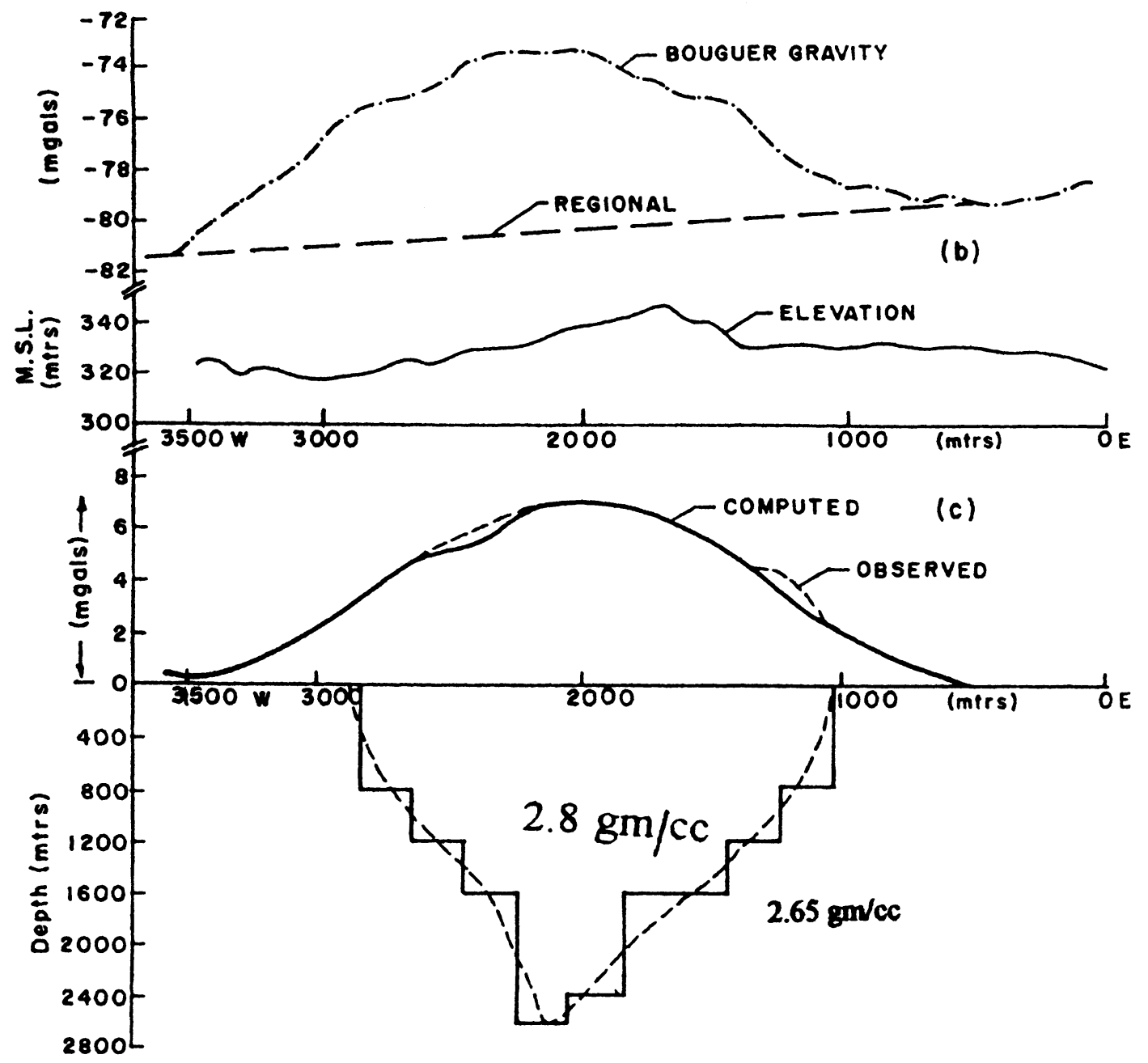

Figure 4. Observed gravity (Bouguer) values, regional, residual and inferred gravity models along traverse I of the Gadwal schist belt, Andhra Pradesh. 




Figure 5. Observed gravity (Bouguer) values, regional, residual and inferred gravity models along traverse II of the Gadwal schist belt, Andhra Pradesh of the Gadwal schist belt, Andhra Pradesh.

8.3 mgal at stations $2000 \mathrm{~m}$ from the start of the profiles on both the traverses. This prominent high and the corresponding slopes indicating a steep gravity gradient are represented by schistose rocks/ older metamorphics that occur as relict patches within the granites and the presence of faults/fractures respectively. Hence, 2-D prism models (Heiland 1968) have been used to interpret residual gravity using a density contrast of $0.15 \mathrm{gm} / \mathrm{cc}$. A linear regional was assumed for interpreting the residual gravity data along profiles I and II. Figures 4 and 5 show the observed and computed gravity data as obtained from forward modeling and the resulting subsurface structure respectively, of the schist belt. It can be seen that the error in the fitted model with respect to the observed data is within $5 \%$, which is fairly acceptable. Further, based on this quantitative estimation of the 2-D gravity model, a $3-\mathrm{D}$ view of the gravity inferred basement for the Gadwal schist belt has been presented in figure 6 .
In view of the considerable literature supporting the basinal structure of schist belts flanked by granite gneiss/amphibolite terrains (Chadwick et al 2000, Krogstad et al 1989), the validity of the present model for the schist belt seems to be established. Thus, to summarize the first order structure inferred reveals that

- The meta-sediments are $1.8 \mathrm{~km}$ wide at the surface and taper at a depth of $2.6-\mathrm{km}$ giving a synformal structure and

- The possible depth extent obtained using a density contrast of $0.15 \mathrm{gm} / \mathrm{cc}$ is about $2.6 \mathrm{~km}$.

\section{Acknowledgements}

The authors acknowledge the financial assistance received from DST and UGC, New Delhi. 

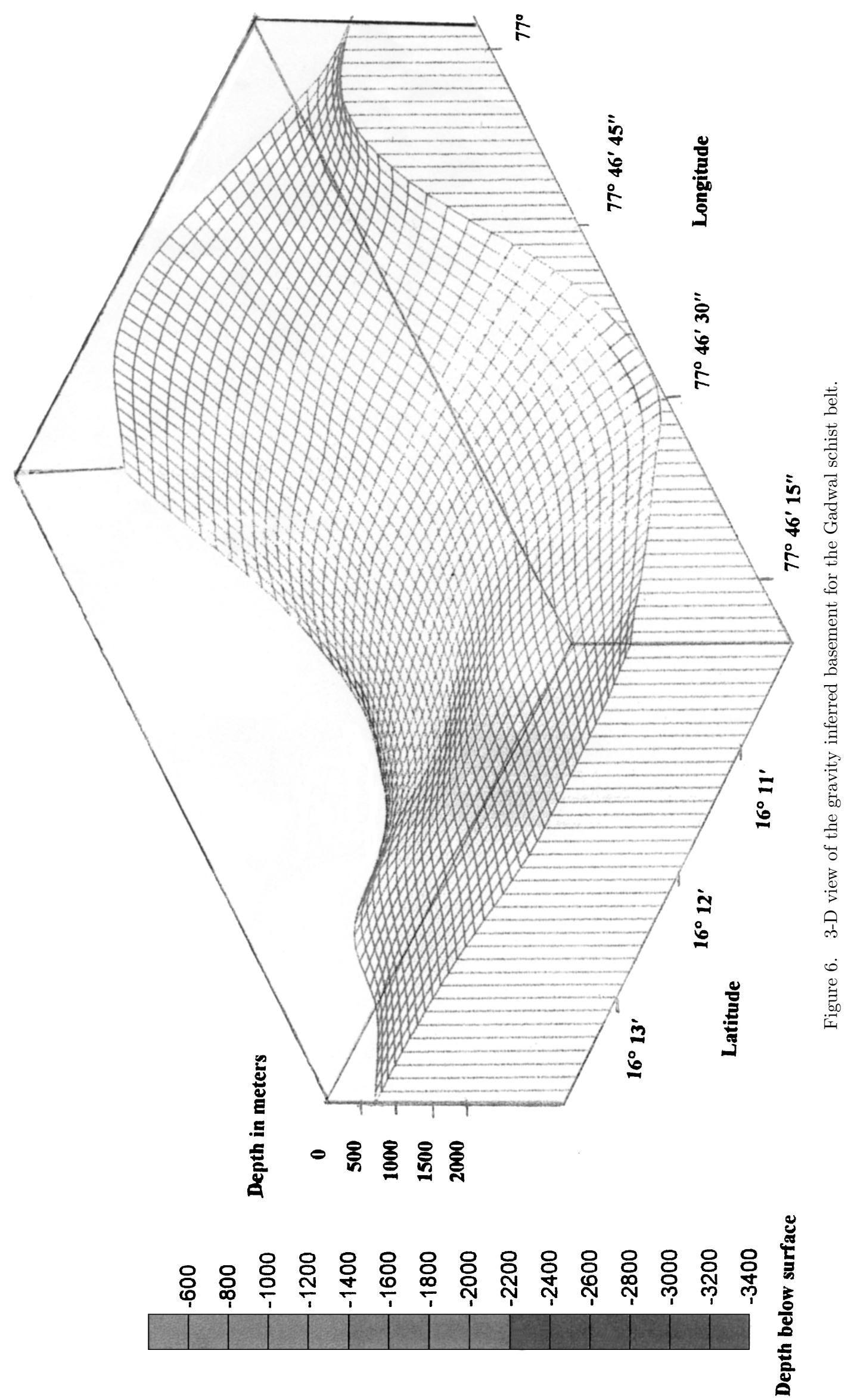


\section{References}

Ananda Murty S and Bhattacharjee S 1997 Occurrence of gold in Guntipalli - Atkur area, Gadwal schist belt, Mahboobnagar district, A P; J. Geol. Soc. India 49 721-722

Appa Rao M, Ananda Reddy R, Chakravarty P and Murty B S R 1996 Targetting areas for gold exploration by potential field surveys: A case study from Hutti - Muski schist belt, Karnataka; Proceedings of the International Seminar and Exhibition on Geophysics beyond 2000 (AEG) 195-196

Balakrishna S, Rajamani V and Hanson G N 1999 U-Pb ages for Zircon and Titanite from the Ramagiri Area, southern, India: Evidence for accretionary origin of the eastern Dharwar craton during the late Archaean; J. Geol 107 69-86

Chadwick B, Vasudev V, Nand Hegde G V 2000 The Dharwar craton, southern India, interpreted as the result of late Archaean oblique convergence; Precamb. Res 99 91-111

Fedensky V V 1967 Exploration Geophysics (Moscow: (Nedra) in Russian) 672

Krishna Brahmam N 1996 Gravity in relation to structure, palaeo-sutures and seismicity of southern India (south of the $16^{\text {th }}$ parallel), Memoir; Geological society of India 25 73-95
Krogstad E J, Balakrishnan S, Mukhopadhyay D K, Rajamani V and Hanson G N 1989 Plate tectonics 2.5 billion years ago: Evidence at Kolar, south India; Reports; Curr. Sc. 243 $1337-1340$

Heiland C A 1968 Geophysical Exploration (New York and London: Hafner)

Subramanyam C 1978 On the relation of gravity analysis to geotectonics of the Precambrian terrain of southern Indian Shield; J. Geol. Soc. India 19 251-263

Subramanyam C 1982 Gravity interpretation of the Dharwar greenstone-gneiss-granite terrain in the south Indian shield and its geological implications; Tectonophysics $\mathbf{8 4}$ 225-245

Reddy P R 1992 Use of IRS data to locate gold mineralization in the Gadwal Schist belt, AP; Interface, a bulletin from the NRSA data center 3, No 2, April 1992

Varaprasada Rao S M and Bhimasankaram V L S 1982 Geophysical investigations for barytes at Gopalpur, Khammam district, A P, India; J. Geol. Soc. India 23 $32-38$

Verma R K 1985 Gravity field, seismicity and tectonics of the Indian peninsular shield and the Himalayas; (Allied Publishers Pvt Ltd) 